\title{
Enhanced Acetone, Butanol, and Ethanol Fermentation by Clostridium saccharoperbutylacetonicum N1-4 (ATCC 13564) in a Chemically Defined Medium: Effect of Iron and Initial pH on ABE Ratio
}

\author{
HANIES AMBARSARI ${ }^{1 * A N D ~ K E N J I ~ S O N O M O T O ~}{ }^{2,3}$ \\ ${ }^{\prime}$ Institute of Environmental Technology (BTL)-Indonesian, Agency for Assessment and Application of Technology (BPPT), \\ Building 412 PUSPIPTEK Serpong, Banten 15314, Indonesia; \\ ${ }^{2}$ Laboratory of Microbial Technology, Division of Microbial Science and Technology, Department of Bioscience and \\ Biotechnology, Faculty of Agriculture, Graduate School, \\ Kyushu University, 6-10-1 Hakozaki, Higashi-ku, Fukuoka 812-8581, Japan; \\ ${ }^{3}$ Laboratory of Functional Food Design, Department of Functional Metabolic Design, Bio-Architecture Center, Kyushu \\ University, 6-10-1 Hakozaki, Higashi-ku, Fukuoka 812-8581, Japan
}

\begin{abstract}
Batch studies were performed to investigate the performance of Clostridium saccharoperbutylacetonicum N1-4 (ATCC 13564) in acetone-butanol-ethanol (ABE) fermentation as affected by iron and initial $\mathrm{pH}$ in defined TYA (Tryptone-Yeast extract-Acetate) media. Different concentrations of $\mathrm{FeSO}_{4} \cdot 7 \mathrm{H}_{2} \mathrm{O}$ in the TYA media were found to influence the $\mathrm{ABE}$ fermentation process resulting in different $\mathrm{ABE}$ ratios. From the experiment with different concentrations of $\mathrm{FeSO}_{4} \cdot 7 \mathrm{H}_{2} \mathrm{O}$, it was also found that lag phases at initial $\mathrm{pH}$ of 4.4 were longer than those at initial $\mathrm{pH}$ of 6.5 , however they could still have higher $\mathrm{ABE}$ productivity values. Addition of $0.003 \mathrm{~g} \mathrm{~L}^{-1}$ $\mathrm{FeSO}_{4} \cdot 7 \mathrm{H}_{2} \mathrm{O}$ could give the highest $\mathrm{ABE}$ production with both initial $\mathrm{pH}$ of 6.5 and 4.4. With more than $0.01 \mathrm{~g} \mathrm{~L}^{-1}$ $\mathrm{FeSO}_{4} \cdot 7 \mathrm{H}_{2} \mathrm{O}$, ratios of acetone to butanol $(0.50-0.53)$ were higher at initial $\mathrm{pH}$ of 4.4 than those $(0.26-0.28)$ at initial $\mathrm{pH}$ of 6.5. Those differences were not obtained with low concentration of $\mathrm{FeSO}_{4} .7 \mathrm{H}_{2} \mathrm{O}$ among the same initial $\mathrm{pH}$. It was also confirmed that initial $\mathrm{pH}$ affected $\mathrm{ABE}$ production significantly more than $\mathrm{FeSO}_{4} \cdot 7 \mathrm{H}_{2} \mathrm{O}$ by statistical analysis.
\end{abstract}

Key words: acetone-butanol-ethanol (ABE), Clostridium saccharoperbutylacetonicum, glucose, initial pH, iron, TYAmedium

Suatu penelitian dilakukan untuk mengetahui kinerja dari mikroba Clostridium saccharoperbutylacetonicum N1-4 (ATCC 13564) dalam proses fermentasi aseton-butanol-etanol (ABE) terutama pengaruh dari pH awal dan penambahan senyawa besi ke dalam media TYA (Tryptone-Yeast extract-Acetate) yang terdefinisi. Konsentrasi senyawa $\mathrm{FeSO}_{4} \cdot 7 \mathrm{H}_{2} \mathrm{O}$ yang berbeda di dalam media TYA ternyata dapat mempengaruhi proses fermentasi $\mathrm{ABE}$ dan menghasilkan rasio $\mathrm{ABE}$ berbeda. Dari penelitian dengan menggunakan konsentrasi senyawa $\mathrm{FeSO}_{4} \cdot 7 \mathrm{H}_{2} \mathrm{O}$ yang berbeda-beda, juga ditemukan bahwa fase lag pada perlakuan $\mathrm{pH}$ awal 4,4 lebih lama daripada perlakuan $\mathrm{pH}$ awal 6,5 tetapi dengan nilai produktivitas $\mathrm{ABE}$ yang lebih tinggi. Penambahan $0,003 \mathrm{~g} \mathrm{~L}^{-1} \mathrm{FeSO}_{4} \cdot 7 \mathrm{H}_{2} \mathrm{O}$ dapat menghasilkan produksi ABE tertinggi pada kedua perlakuan $\mathrm{pH}$ awal 6,5 dan 4,4. Dengan penambahan lebih dari $0,01 \mathrm{~g} \mathrm{~L}^{-1} \mathrm{FeSO}_{4} \cdot 7 \mathrm{H}_{2} \mathrm{O}$, rasio aseton terhadap butanol $(0,50-0,53)$ lebih tinggi pada perlakuan $\mathrm{pH}$ awal 4,4 daripada perlakuan $\mathrm{pH}$ awal $6,5(0,26-0,28)$. Perbedaan itu tidak ditemui pada penambahan senyawa $\mathrm{FeSO}_{4} \cdot 7 \mathrm{H}_{2} \mathrm{O}$ dengan konsentrasi yang lebih rendah pada $\mathrm{pH}$ awal yang sama. Dari analisa statistika terhadap data yang diperoleh dalam penelitian ini, dapat dibuktikan juga bahwa pengaruh $\mathrm{pH}$ awal secara signifikan lebih besar daripada pengaruh penambahan senyawa $\mathrm{FeSO}_{4} \cdot 7 \mathrm{H}_{2} \mathrm{O}$ terhadap proses fermentasi $\mathrm{ABE}$ di dalam media TYA yang terdefinisi.

Kata kunci: aseton-butanol-etanol (ABE), Clostridium saccharoperbutylacetonicum, glukosa, media TYA, pH awal

In the fermentation process, acetone, butanol, and ethanol are generally produced with butanol as the major product (Qureshi et al. 2006), hence it is generally called as butanol or ABE (acetone-butanolethanol) fermentation. ABE fermentation has been gaining a lot of interest worldwide due to the raising production cost of petroleum-based chemicals and fuels (Tashiro and Sonomoto 2010). In particular,

*Corresponding author; Phone: +62-21-7560919, Fax: +6221-7563116, E-mail: hanies.ambarsari@gmail.com butanol is the most promising solvent compared to acetone and ethanol, because butanol has a lower vapour pressure but a higher energy content, hence it is safer and more economical. Additionally, butanolgasoline blends are less susceptible to separation because butanol has a higher tolerance to water contamination in the blends. This facilitates the use of butanol in existing gasoline supply and distribution channels. Butanol can also be blended with gasoline at higher concentrations than ethanol without requiring of 
vehicles modification (Hipolito et al. 2008; Qureshi and Blaschek 2001).

In a normal batch culture, solvent-producing Clostridium species produce hydrogen, carbon dioxide, acetate and butyrate during the initial growth phase (acidogenic phase), resulting in a decrease of the $\mathrm{pH}$ in the culture medium. The metabolism of the cells then switches to solvent production (solventogenic phase) as the culture enters the stationary growth phase, during which the reassimilation of acids occurs concurrently with the continued consumption of the carbohydrate and the medium $\mathrm{pH}$ normally increases (Jones and Woods 1986). The complex multibranched fermentation pathways of Clostridium acetobutylicum provide an excellent system for the study of metabolic regulation in clostridia. Of particular interest are the changes in carbon and electron flow during such fermentation and the regulation of these changes. It is very important to understand the factors involved in triggering the metabolic transition and the physiological state associated with the transition from the acidogenic to the solventogenic phase in which the production of solvents IS initiated and maintained. One of such factors is the role of nutrient limitation.

The effect of nutrient factors on the onset and maintenance of $\mathrm{ABE}$ production has been investigated by a number of workers, in both batch- and continuousculture systems employing Clostridium acetobutylicum, C. beijerinckii, or C. pasteurianum strains (Heluane et al. 2011; Amador-Noguez et al. 2010; Awang et al. 1992; Bahl and Gottschalk 1984; Dabrock et al. 1992; Junelles, et al. 1988; Monot et al. 1982). The influence of $\mathrm{pH}$ has been recognized as a key factor in determining the outcome of $\mathrm{ABE}$ fermentation. Many of early reports noted that the initiation of $\mathrm{ABE}$ production occurred only after the $\mathrm{pH}$ had decreased to around 4.5 to 5.0 , and recent studies also confirmed that cultures maintained at high $\mathrm{pH}$ produced mainly acids, whereas those maintained at a low $\mathrm{pH}$ predominantly produced $\mathrm{ABE}$. Nevertheless, the $\mathrm{pH}$ range over which $\mathrm{ABE}$ formation may occur appears to vary quite widely depending on the particular strain and the culture conditions used. For examples, a number of $C$. acetobutylicum DSM strains could only produce $\mathrm{ABE}$ at below about $\mathrm{pH} 5.0$ (Bahl et al. 1982; Nishio et al. 1983), while the $C$. acetobutylicum type culture strain ATCC 824 has been reported to produce good levels of ABE between $\mathrm{pH} 5.5$ and 4.3 (Monot et al.1984).

However, to the best of our knowledge, only a limited number of studies have been done to investigate the nutritional and environmental factors affecting the $\mathrm{ABE}$ fermentation by C. saccharoperbutylacetonicum N1-4 (ATCC 13564). In particular, the effects of nutrients contained in the TYA (Tryptone-Yeast extract-Acetate) medium, which has usually been used in the $\mathrm{ABE}$ fermentation process by strain N1-4, such as iron, phosphate, magnesium, ammonium, sulfate, and potassium sources have not been investigated in detail. There was a previous study by a research group in British Columbia, Canada investigating the influence of culture parameters on biological hydrogen production by $C$. saccharoperbutylacetonicum ATCC 27021, but they only focused on the hydrogen production and the parameters they studied were the carbon and nitrogen sources, iron, inoculum size, initial $\mathrm{pH}$ and agitation speed (Ferchichi et al. 2005). The objective of the present work is to study the effect of iron contained in the TYA media, as well as the initial $\mathrm{pH}$, on the $\mathrm{ABE}$ fermentation by strain N1-4 using glucose as the substrate.

\section{MATERIALS AND METHODS}

Microorganism Preparation. For a long-term stock culture, strain N1-4 was previously kept as spores in sterilized sand, while for short-term storage, it was maintained in $15 \%$ PG (potato glucose) medium containing substances mentioned in previous reports (Hipolito et al. 2008; Tashiro et al. 2007). For refreshing the stock culture, per $1 \mathrm{~mL}$ of this stock was transferred into $9 \mathrm{~mL}$ of fresh PG medium, heatshocked in boiling water for $1 \mathrm{~min}$, cooled in iced water for several minutes and anaerobically incubated at 30 ${ }^{\circ} \mathrm{C}$ for $28 \mathrm{~h}$ without agitation or $\mathrm{pH}$ control.

Pre-Culture Media. The refresh culture was then transferred into TYA (Tryptone-Yeast extract-Acetate) fresh medium to pre-culture the bacteria anaerobically at $30{ }^{\circ} \mathrm{C}$ for $15 \mathrm{~h}$ without agitation and $\mathrm{pH}$ control. The conventional TYA medium components per liter of distilled water were $6 \mathrm{~g}$ of bactotryptone (Difco, Detroit, MI, USA), $2 \mathrm{~g}$ of yeast extract (Difco), $3 \mathrm{~g}$ of $\mathrm{CH}_{3} \mathrm{COONH}_{4}, 0.5 \mathrm{~g}$ of $\mathrm{KH}_{2} \mathrm{PO}_{4}, 0.3 \mathrm{~g}$ of $\mathrm{MgSO}_{4} \cdot 7 \mathrm{H}_{2} \mathrm{O}$, and $10 \mathrm{mg}$ of $\mathrm{FeSO}_{4} \cdot 7 \mathrm{H}_{2} \mathrm{O}$. The initial $\mathrm{pH}$ of this TYA pre-culture medium was adjusted to 6.5 with $1 \mathrm{~N}$ $\mathrm{NaOH}$ or $1 \mathrm{~N} \mathrm{HCl}$, and glucose was then added into the medium to constitute a $20 \mathrm{~g} \mathrm{~L}^{-1}$ glucose concentration before it was sterilized at $115^{\circ} \mathrm{C}$ for $15 \mathrm{~min}$.

Main Culture Fermentation. Main batch culture media for the fermentation experiment were prepared similarly to the pre-culture medium except the use of various concentrations of $\mathrm{FeSO}_{4} \cdot 7 \mathrm{H}_{2} \mathrm{O}$ contained in the TYA medium, as well as two different initial $\mathrm{pH}$ values, $\mathrm{pH} 6.5$ and $\mathrm{pH}$ 4.4. The main culture medium for each 
treatment was prepared in a $500 \mathrm{~mL}$ flask with the working volume of $250 \mathrm{~mL}$, glucose concentration of $20 \mathrm{~g} \mathrm{~L}^{-1}$, and the initial $\mathrm{pH}$ of 6.5 or 4.4 adjusted by adding $1 \mathrm{~N} \mathrm{NaOH}$ or $1 \mathrm{~N} \mathrm{HCl}$, after which was sterilized at $115{ }^{\circ} \mathrm{C}$ for $15 \mathrm{~min}$. The inoculum was $10 \%$ (v/v) of the culture volume. Following inoculation, the broth was sparged with filtered oxygen-free nitrogen gas for 20 min to maintain strict anaerobic conditions. All cultivations were static batch fermentations conducted anaerobically at $30{ }^{\circ} \mathrm{C}$ without $\mathrm{pH}$ control and agitation until the end of fermentation time.

Different concentrations of $\mathrm{FeSO}_{4} \cdot 7 \mathrm{H}_{2} \mathrm{O}$ were used in this experiment to investigate the effects of such different iron concentrations on the ABE fermentation by the strain N1-4 in the defined TYA media. The concentrations used were $0,0.003,0.01$, and $0.025 \mathrm{~g} \mathrm{~L}^{-1}$ $\mathrm{FeSO}_{4} \cdot 7 \mathrm{H}_{2} \mathrm{O}$, each of which was applied at initial $\mathrm{pH}$ 6.5 or 4.4 with glucose concentration of $20 \mathrm{~g} \mathrm{~L}^{-1}$ as the substrate. The $0.01 \mathrm{~g} \mathrm{~L}^{-1} \mathrm{FeSO}_{4} \cdot 7 \mathrm{H}_{2} \mathrm{O}$ with initial $\mathrm{pH}$ 6.5 was used as the control treatment since it was the condition normally defined for a TYA medium.

The followings are the treatment label codes applied during the experiment $(\mathrm{G}=$ glucose; $\mathrm{F}=$ $\left.\mathrm{FeSO}_{4} \cdot 7 \mathrm{H}_{2} \mathrm{O} ; \mathrm{p}=\mathrm{pH}\right)$ : TYA with no iron $\left(0 \mathrm{~g} \mathrm{~L}^{-1}\right.$ $\mathrm{FeSO}_{4} \cdot 7 \mathrm{H}_{2} \mathrm{O}$ ) (negative control), initial pH 6.5 (= GF0p6); TYA with no iron $\left(0 \mathrm{~g} \mathrm{~L}^{-1} \mathrm{FeSO}_{4} \cdot 7 \mathrm{H}_{2} \mathrm{O}\right)$, initial pH 4.4 (= GF0p4), TYA containing $0.003 \mathrm{~g} \mathrm{~L}^{-1}$ $\mathrm{FeSO}_{4} \cdot 7 \mathrm{H}_{2} \mathrm{O}$ (iron-limited), initial pH 6.5 (= GF3p6); TYA containing $0.003 \mathrm{~g} \mathrm{~L}^{-1} \mathrm{FeSO}_{4} .7 \mathrm{H}_{2} \mathrm{O}$, initial $\mathrm{pH} 4.4$ (= GF3p4); TYA containing $0.01 \mathrm{~g} \mathrm{~L}^{-1} \mathrm{FeSO}_{4} \cdot 7 \mathrm{H}_{2} \mathrm{O}$ (positive control), initial pH 6.5 (= GF10p6); TYA containing $0.01 \mathrm{~g} \mathrm{~L}^{-1} \mathrm{FeSO}_{4} \cdot 7 \mathrm{H}_{2} \mathrm{O}$, initial $\mathrm{pH} 4.4$ (= GF10p4); TYA containing $0.025 \mathrm{~g} \mathrm{~L}^{-1} \mathrm{FeSO}_{4} .7 \mathrm{H}_{2} \mathrm{O}$ (iron-excess), initial pH $6.5(=\mathrm{GF} 25 \mathrm{p} 6)$; TYA containing $0.025 \mathrm{~g} \mathrm{~L}^{-1} \mathrm{FeSO}_{4} \cdot 7 \mathrm{H}_{2} \mathrm{O}$, initial pH 4.4 (= GF25p4).

Sampling and Analysis. Sampling was performed periodically at every $6 \mathrm{~h}$. One set of the samples was centrifuged with $20400 \mathrm{x}$ g at $4{ }^{\circ} \mathrm{C}$ for $10 \mathrm{~min}$ using a high speed refrigerated micro centrifuge (TOMY MX300; TOMY TECH, U.S.A. Inc., Tokyo, Japan) and supernatants were obtained. The supernatants were analyzed for the acids and $\mathrm{ABE}$ concentrations using a gas chromatograph (6890A; Agilent Technologies, Palo Alto, Ca, USA) equipped with a flame ionization detector and a 15-m capillary column (Innowax; i.d. $0.53 \mathrm{~mm}$; 19095N-121; Agilent Technologies) using isobutanol as the internal standard with $1 \mathrm{M} \mathrm{HCl}$ (Tashiro et al. 2004). The glucose concentration in the supernatant was determined with a glucose analyzer (Biosensor BF-5; Oji Scientific Instrument, Osaka,
Japan). Another set of the samples was directly analyzed for the $\mathrm{pH}$, the bacterial density and the total sugar concentration. The $\mathrm{pH}$ values were measured using the pH-meter. The bacterial growth was monitored over time as the culture turbidity (OD 562 $\mathrm{nm}$ ) with a spectrophotometer (V-530; JASCO, Tokyo, Japan). The residual total sugar was measured by a spectrophotometer (V-530) applying the phenolsulfuric-acid method described in detail elsewhere (Dubois et al. 1956).

Calculation and Statistical Analysis. As mentioned previously (Jesse et al. 2002), the ABE concentration $\left(\mathrm{g} \mathrm{L}^{-1}\right)$ was defined as the difference between the $\mathrm{ABE}$ at the indicated fermentation time and that at the beginning of period. The ABE yield (ggT $\left.\mathrm{S}^{-1}\right)$ was calculated as the ABE $\left(\mathrm{g} \mathrm{L}^{-1}\right)$ produced at the indicated fermentation time divided by the total sugar ( $\mathrm{g} \mathrm{L}^{-1}$ ) being utilized at the same period (Formanek et al. 1997). These definitions were also used to calculate the concentration of each product (acetone, butanol, or ethanol) and the butanol yield $\left.(\mathrm{ggT} \mathrm{S})^{-1}\right)$. The $\mathrm{ABE}$ productivity $\left(\mathrm{g} \mathrm{L}^{-1} \mathrm{~h}^{-1}\right)$ was defined as the $\mathrm{ABE}$ concentration $\left(\mathrm{g} \mathrm{L}^{-1}\right)$ produced per hour. The ABE ratio was defined as the ratio of acetone:butanol:ethanol by using butanol as the standard of calculation.

Statistical analysis was carried out with Microsoft Office Excel 2003 ANOVA Two-Factor without Replication (Microsoft Inc., USA). It was defined that if $\mathrm{P}$-value $<0.05$ and $\mathrm{F}$-value $\mathrm{F}$-critical, it could be suggested that there was a significant effect of the treatment variations (nutrient concentrations or initial $\mathrm{pH}$ ) on the $\mathrm{ABE}$ fermentation process (production of acetone, butanol, ethanol, or ABE) (Devore and Peck 1993).

\section{RESULTS}

Lag phases at initial $\mathrm{pH}$ of 4.4 were longer than those at initial $\mathrm{pH}$ of 6.5 , however, the $\mathrm{ABE}$ production with initial $\mathrm{pH} 4.4$ in each iron concentration applied was higher (Fig 1A and B, Fig 2A, Table 1). The ABE productivity was calculated at $48 \mathrm{~h}$ fermentation period, since the maximum $\mathrm{ABE}$ concentrations in almost all treatments, especially those with initial $\mathrm{pH}$ 4.4, could be obtained after this period. The highest ABE concentration $\left(11 \mathrm{~g} \mathrm{~L}^{-1}\right.$ as stated in Table 1$)$ was achieved at $48 \mathrm{~h}$ by adding $0.003 \mathrm{~g} \mathrm{~L}^{-1} \mathrm{FeSO}_{4} \cdot 7 \mathrm{H}_{2} \mathrm{O}$ into the TYA medium with initial $\mathrm{pH}$ 4.4. Comparing the treatments added by the same iron concentrations but different initial $\mathrm{pH}$, it was revealed that all such treatments with initial $\mathrm{pH} 4.4$ could obtain higher $\mathrm{ABE}$ 
yield and productivity. Using $0.025 \mathrm{~g} \mathrm{~L}^{-1} \mathrm{FeSO}_{4} \cdot 7 \mathrm{H}_{2} \mathrm{O}$ at initial $\mathrm{pH} 6.5$, strain $\mathrm{N} 1-4$ could obtain $0.31 \mathrm{ggT} \mathrm{S}^{-1}$, $0.41 \mathrm{ggT} \mathrm{S}^{-1}$, and $0.18 \mathrm{~g} \mathrm{~L}^{-1} \mathrm{~h}^{-1}$ for the butanol yield, $\mathrm{ABE}$ yield, and $\mathrm{ABE}$ productivity, respectively, but at initial
$0.38 \mathrm{ggT} \mathrm{S}^{-1}, 0.51 \mathrm{ggT} \mathrm{S}^{-1}$, and $0.22 \mathrm{~g} \mathrm{~L}^{-1} \mathrm{~h}^{-1}$, respectively with initial $\mathrm{pH} 4.4$, and $6.8 \mathrm{~g} \mathrm{~L}^{-1}, 0.32 \mathrm{ggT} \mathrm{S}^{-1}, 0.43 \mathrm{ggT}$ $\mathrm{S}^{-1}$, and $0.19 \mathrm{~g} \mathrm{~L}^{-1} \mathrm{~h}^{-1}$, respectively with initial $\mathrm{pH} 6.5$ (Table 1). Hence it could be proposed that the optimum
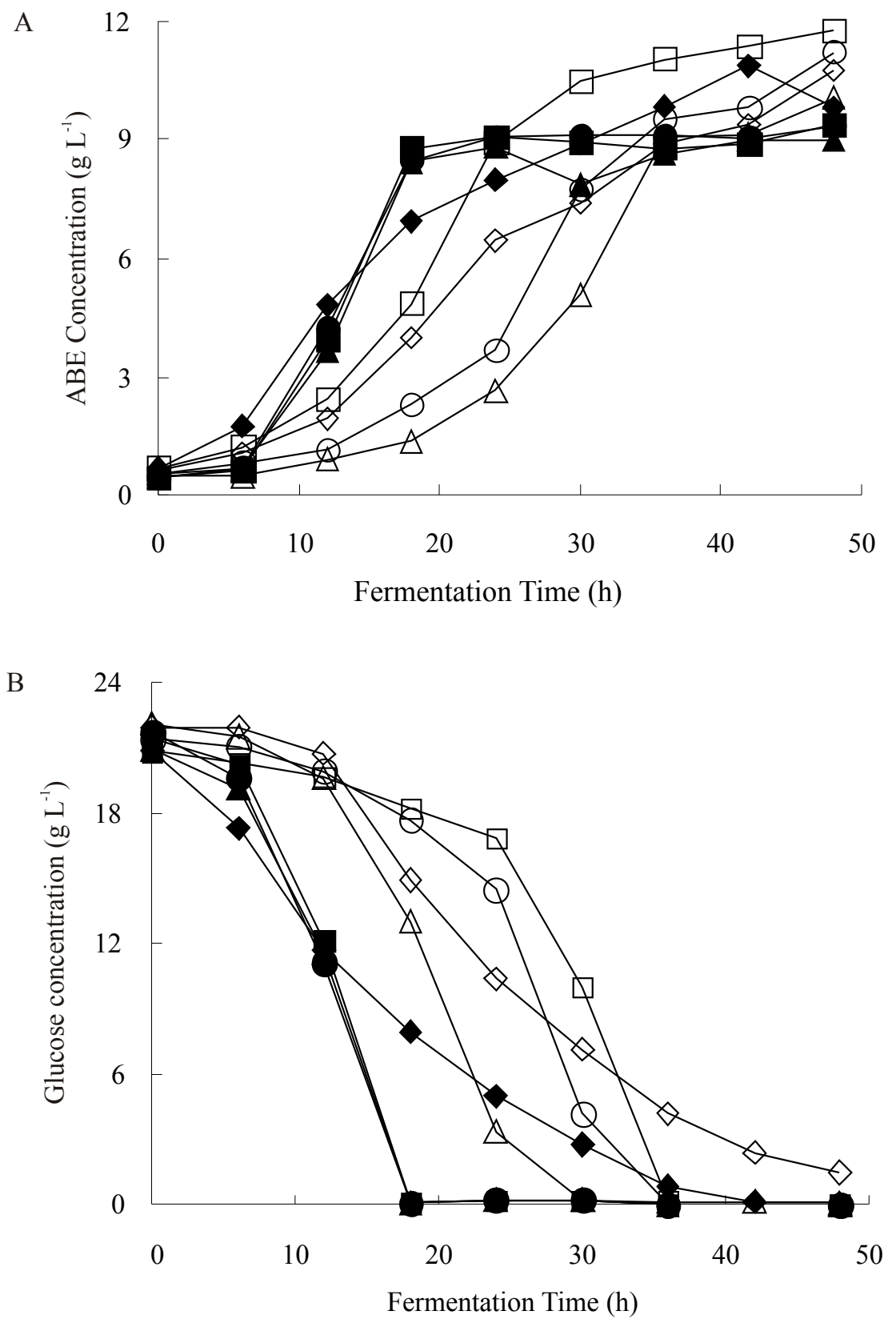

Fig 1 ABE concentration (A) and glucose consumption (B) during ABE fermentation by C. saccharoperbutylacetonicum N1-4 (ATCC 13564) using glucose with different $\mathrm{FeSO}_{4} \cdot 7 \mathrm{H}_{2} \mathrm{O}$ concentrations in defined TYA media. Fermentation conditions: initial $\mathrm{pH}=6.5$ or 4.4 ; working volume $=250 \mathrm{ml}$; static batch culture without $\mathrm{pH}$ control. Symbols: $(\diamond) \mathrm{GF} 0 \mathrm{p} 6 ;(\diamond)$

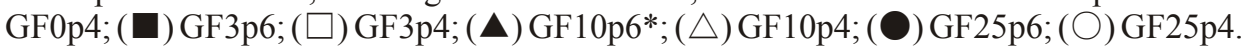

$\mathrm{pH} 4.4$ it could obtain higher values of such parameters, which were $0.32 \mathrm{ggT} \mathrm{S}^{-1}, 0.50 \mathrm{ggT} \mathrm{S}^{-1}$, and $0.22 \mathrm{~g} \mathrm{~L}^{-1} \mathrm{~h}^{-1}$, respectively (Table 1 ).

Addition of $0.003 \mathrm{~g} \mathrm{~L}^{-1} \mathrm{FeSO}_{4} \cdot 7 \mathrm{H}_{2} \mathrm{O}$ gave the highest $\mathrm{ABE}$ production with either initial $\mathrm{pH} 4.4$ or 6.5 , with the values of butanol concentration, butanol yield, ABE yield, and ABE productivity were $7.9 \mathrm{~g} \mathrm{~L}^{-1}$, condition for strain N1-4 to produce high ABE in a TYA medium with glucose as the substrate is by using 0.003 $\mathrm{g} \mathrm{L}^{-1} \mathrm{FeSO}_{4} \cdot 7 \mathrm{H}_{2} \mathrm{O}$. Interestingly, the treatment GF0p4 (using no iron with initial $\mathrm{pH} 4.4$ ) could be suggested as the more efficient condition than treatment GF10p6* (using $0.01 \mathrm{~g} \mathrm{~L}^{-1} \mathrm{FeSO}_{4} \cdot 7 \mathrm{H}_{2} \mathrm{O}$ with initial $\mathrm{pH} 6.5$ as the positive control treatment), since strain N1-4 in GF0p4 
Table 1 Effect of different $\mathrm{FeSO}_{4} \cdot 7 \mathrm{H}_{2} \mathrm{O}$ concentrations and initial $\mathrm{pH}$ on $\mathrm{ABE}$ fermentation by Clostridium saccharoperbutylacetonicum N1-4 (ATCC 13564) using glucose in defined TYA media at $48 \mathrm{~h}$ fermentation time

\begin{tabular}{lccccccccc}
\hline C-Sources & $\begin{array}{c}\text { Acetone } \\
\left(\mathrm{g} \mathrm{L}^{-1}\right)\end{array}$ & $\begin{array}{c}\text { Butanol } \\
\left(\mathrm{g} \mathrm{L}^{-1}\right)\end{array}$ & $\begin{array}{c}\text { Ethanol } \\
\left(\mathrm{g} \mathrm{L}^{-1}\right)\end{array}$ & $\begin{array}{c}\mathrm{ABE} \\
\left(\mathrm{g} \mathrm{L}^{-1}\right)\end{array}$ & $\begin{array}{c}\text { Consumed } \\
\text { substrate } \\
\left(\mathrm{g} \mathrm{L}^{-1}\right)\end{array}$ & $\begin{array}{c}\text { ABE } \\
\text { ratio }\end{array}$ & $\begin{array}{c}\text { Butanol } \\
\text { yield } \\
\left(\mathrm{ggT} \mathrm{S}^{-1}\right)\end{array}$ & $\begin{array}{c}\text { ABE } \\
\text { yield } \\
\left(\mathrm{ggT} \mathrm{S}^{-1}\right)\end{array}$ & $\begin{array}{c}\text { ABE } \\
\text { productivity } \\
\left(\mathrm{g} \mathrm{L}^{-1} \mathrm{~h}^{-1}\right)\end{array}$ \\
\hline GF0p6 & 3.0 & 5.7 & 0.34 & 9.1 & 21 & $0.53: 1: 0.06$ & 0.28 & 0.44 & 0.19 \\
GF0p4 & 3.4 & 6.3 & 0.47 & 10 & 20 & $0.53: 1: 0.07$ & 0.31 & 0.49 & 0.21 \\
GF3p6 & 2.1 & 6.8 & 0.20 & 9.1 & 21 & $0.31: 1: 0.03$ & 0.32 & 0.43 & 0.19 \\
GF3p4 & 2.5 & 7.9 & 0.26 & 11 & 21 & $0.32: 1: 0.03$ & 0.38 & 0.51 & 0.22 \\
GF10p6* & 1.7 & 6.1 & 0.37 & 8.2 & 21 & $0.28: 1: 0.06$ & 0.29 & 0.39 & 0.17 \\
GF10p4 & 3.0 & 6.0 & 0.51 & 9.6 & 22 & $0.50: 1: 0.08$ & 0.27 & 0.43 & 0.20 \\
GF25p6 & 1.7 & 6.8 & 0.35 & 8.9 & 22 & $0.26: 1: 0.05$ & 0.31 & 0.41 & 0.18 \\
GF25p4 & 3.5 & 6.8 & 0.33 & 11 & 21 & $0.51: 1: 0.05$ & 0.32 & 0.50 & 0.22 \\
\hline
\end{tabular}

The followings are the treatment label codes applied during the experiment $\left(\mathrm{G}=\right.$ glucose; $\left.\mathrm{F}=\mathrm{FeSO}_{4} \cdot 7 \mathrm{H}_{2} \mathrm{O} ; \mathrm{p}=\mathrm{pH}\right)$ : TYA with no iron $\left(0 \mathrm{~g} \mathrm{~L}^{-1} \mathrm{FeSO}_{4} \cdot 7 \mathrm{H}_{2} \mathrm{O}\right)$ (negative control), initial pH 6.5 (= GF0p6); TYA with no iron $\left(0 \mathrm{~g} \mathrm{~L}^{-1} \mathrm{FeSO}_{4} .7 \mathrm{H}_{2} \mathrm{O}\right)$, initial pH 4.4 (= GF0p4); TYA containing $0.003 \mathrm{~g} \mathrm{~L}^{-1} \mathrm{FeSO}_{4} \cdot 7 \mathrm{H}_{2} \mathrm{O}$ (iron-limited), initial pH 6.5 (= GF3p6); TYA containing $0.003 \mathrm{~g} \mathrm{~L}^{-1}$ $\mathrm{FeSO}_{4} \cdot 7 \mathrm{H}_{2} \mathrm{O}$, initial pH 4.4 (= GF3p4); TYA containing $0.01 \mathrm{~g} \mathrm{~L}^{-1} \mathrm{FeSO}_{4} \cdot 7 \mathrm{H}_{2} \mathrm{O}$ (positive control), initial pH 6.5 (= GF10p6*); TYA containing $0.01 \mathrm{~g} \mathrm{~L}^{-1} \mathrm{FeSO}_{4} \cdot 7 \mathrm{H}_{2} \mathrm{O}$, initial $\mathrm{pH} 4.4$ (=GF10p4); TYA containing $0.025 \mathrm{~g} \mathrm{~L}^{-1} \mathrm{FeSO}_{4} \cdot 7 \mathrm{H}_{2} \mathrm{O}$ (iron-excess), initial pH 6.5 (=GF25p6); TYA containing $0.025 \mathrm{~g} \mathrm{~L}^{-1} \mathrm{FeSO}_{4} .7 \mathrm{H}_{2} \mathrm{O}$, initial pH 4.4 (=GF25p4).

could obtain higher yields of butanol and ABE as well as higher $\mathrm{ABE}$ productivity than in GF10p6*. In addition, strain N1-4 in treatment GF0p6 (the negative control treatment) could also produce higher $\mathrm{ABE}$ yield and productivity than in GF10p6*.

The ABE ratio in treatments using different iron concentrations but the same initial $\mathrm{pH}$ could be changed, as well as the ABE ratio in treatments using the same iron concentration but different initial $\mathrm{pH}$ values (Table 1). The ABE ratio with initial $\mathrm{pH} 6.5$ using different iron concentrations in treatment GF0p6 was $0.53: 1: 0.06$, but in treatment GF3p6 it changed to $0.31: 1: 0.03$, then to $0.28: 1: 0.06$ in treatment GF10p6 (the positive control), and to 0.26:1:0.05 in treatment GF25p6. Similarly, the ABE ratio with initial $\mathrm{pH} 4.4$ in treatment GF0p4 was 0.53:1:0.07, but then it could change to $0.32: 1: 0.03$ in treatment GF3p4, or to 0.50:1:0.08 in treatment GF10p4, or to 0.51:1:0.05 in treatment GF25p4. The ABE ratio changes in treatments by using the same iron concentration but different initial $\mathrm{pH}$ values was clearly demonstrated in treatments which used $0.010 \mathrm{~g} \mathrm{~L}^{-1}$ or higher concentrations. In treatment GF0p6 the ABE ratio was 0.53:1:0.06, which was almost similar to the ratio in treatment GF0p4 (0.53:1:0.07). Also in treatment GF3p6 the ratio was $0.31: 1: 0.03$, almost similar to that in treatment GF3p4 (0.32:1:0.03). However, in treatment GF10p6 the ratio was $0.28: 1: 0.06$, that very much different from the ratio in treatment GF10p4 (0.50:1:0.08); also the ratio in treatment GF25p6 was 0.26:1:0.05, very much different from the ratio in treatment GF25p4 (0.51:1:0.05). Since the ethanol concentration was very low compared to those of acetone and butanol, the ABE ratio could be expressed as the ratio of acetone to butanol only. It was found that with more than $0.01 \mathrm{~g} \mathrm{~L}^{-1} \mathrm{FeSO}_{4} .7 \mathrm{H}_{2} \mathrm{O}, \mathrm{ABE}$ ratios of acetone to butanol $(0.50-0.53)$ were higher at initial $\mathrm{pH}$ of 4.4 than that $(0.26-0.28)$ at initial $\mathrm{pH}$ of 6.5 , while those differences were not obtained with low concentration of $\mathrm{FeSO}_{4} \cdot 7 \mathrm{H}_{2} \mathrm{O}$ among the same initial $\mathrm{pH}$ (Table 1).

The $\mathrm{pH}$ on all media with initial $\mathrm{pH} 6.5$ demonstrates a similar trend, which was decreasing up to $6 \mathrm{~h}$, then increasing as the ABE production initiated, except in the medium GF0p6 that slightly decreasing again after $18 \mathrm{~h}$ up to the end of sampling period (Fig 2B). The trend of $\mathrm{pH}$ change in media with initial $\mathrm{pH}$ 4.4 was different from those with initial $\mathrm{pH}$ 6.5. The $\mathrm{pH}$ on all media with initial $\mathrm{pH} 4.4$ were all increasing from the beginning until the end of fermentation time, except in the treatment GF0p4 in which the $\mathrm{pH}$ started to decrease after $30 \mathrm{~h}$.

Initial $\mathrm{pH}$ affected total $\mathrm{ABE}$ significantly more than $\mathrm{FeSO}_{4} \cdot 7 \mathrm{H}_{2} \mathrm{O}$ by statistical analysis (Table 2). Data in Table 2 indicate that only the initial $\mathrm{pH}$ effect on $\mathrm{ABE}$ has the $\mathrm{P}$-value $<0.05(\mathrm{P}$-value $=0.003)$ and $\mathrm{F}$ value $>$ F-critical, meaning that the initial $\mathrm{pH}$ had a significant effect on the ABE production by strain N14 , and that the effect of initial $\mathrm{pH}$ was much greater than 
the effect of $\mathrm{FeSO}_{4} \cdot 7 \mathrm{H}_{2} \mathrm{O}$ different concentrations on the ABE production in the TYA media using glucose as the substrate.

Finally, from the experiment using different concentration of $\mathrm{FeSO}_{4} \cdot 7 \mathrm{H}_{2} \mathrm{O}$, it can be concluded that
$\mathrm{FeSO}_{4} .7 \mathrm{H}_{2} \mathrm{O}$ by statistical analysis.

\section{DISCUSSION}

During the course of glucose fermentation by
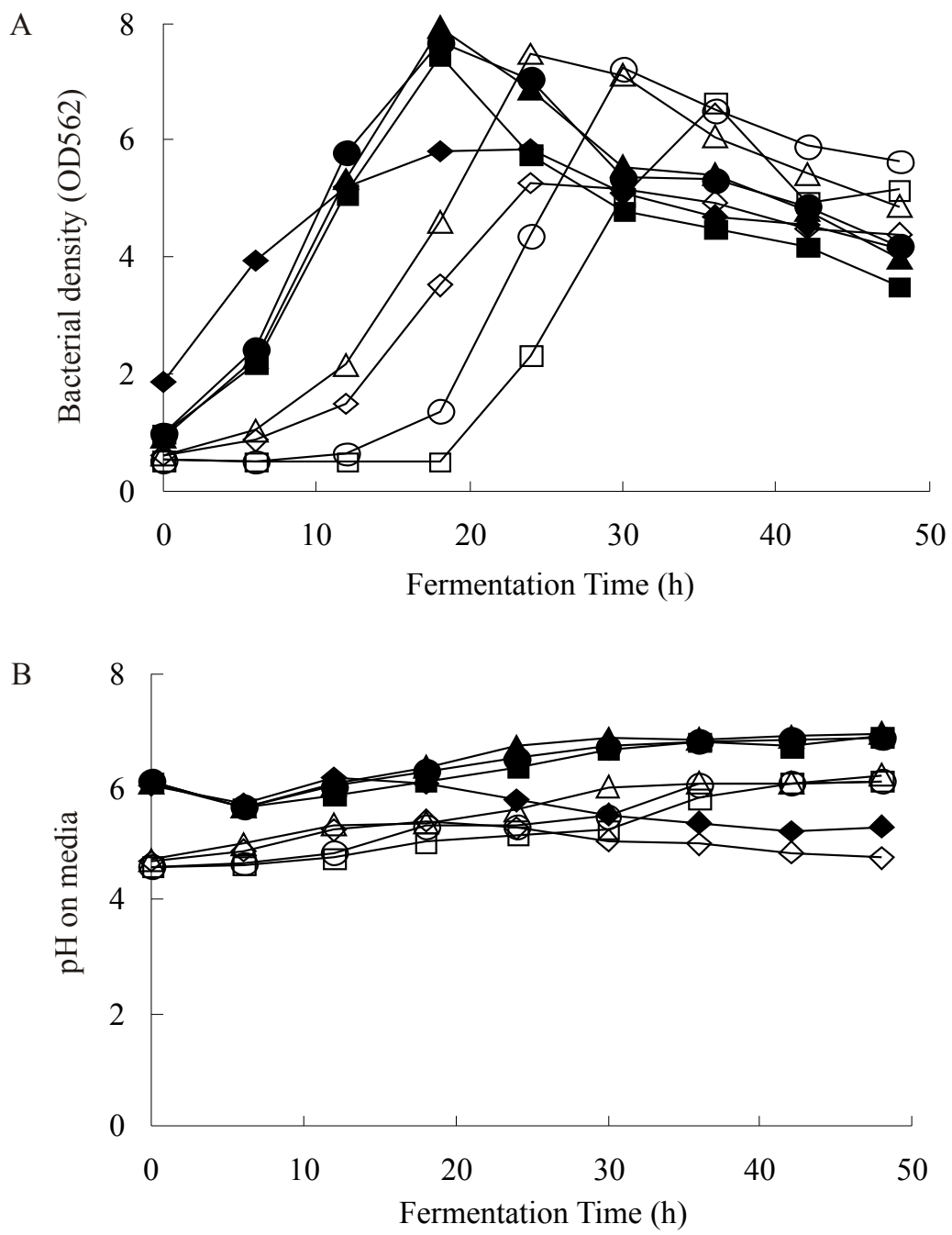

Fig 2 Bacterial density (A) and pH on media (B) during ABE fermentation by C. saccharoperbutylacetonicum N1-4 (ATCC 13564) using glucose with different $\mathrm{FeSO}_{4} .7 \mathrm{H}_{2} \mathrm{O}$ concentrations in defined TYA media. Fermentation conditions: initial $\mathrm{pH}=6.5$ or 4.4 ; working volume $=250 \mathrm{~mL}$; static batch culture without $\mathrm{pH}$ control. Symbols: $(\diamond) \mathrm{GF0p6;}(\diamond) \mathrm{GF} 0 \mathrm{p} 4$; (ロ) GF3p6; $(\square) \mathrm{GF} 3 p 4 ;(\boldsymbol{\Delta}) \mathrm{GF} 10 \mathrm{p} 6 * ;(\triangle) \mathrm{GF} 10 \mathrm{p} 4 ;(\bigcirc) \mathrm{GF} 25 \mathrm{p} 6 ;(\bigcirc) \mathrm{GF} 25 \mathrm{p} 4$.

even though the lag phases at initial $\mathrm{pH}$ of 4.4 were longer than those at initial $\mathrm{pH}$ of 6.5 , however they could still have higher ABE productivity values. It was demonstrated that the addition of $0.003 \mathrm{~g} \mathrm{~L}^{-1}$ $\mathrm{FeSO}_{4} \cdot 7 \mathrm{H}_{2} \mathrm{O}$ gave the highest $\mathrm{ABE}$ production with both initial $\mathrm{pH}$ of 6.5 and 4.4. With more than $0.01 \mathrm{~g} \mathrm{~L}^{-1}$ $\mathrm{FeSO}_{4} \cdot 7 \mathrm{H}_{2} \mathrm{O}$, ABE ratios of acetone to butanol $(0.50$ $0.53)$ were higher at initial $\mathrm{pH}$ of 4.4 than that $(0.26$ 0.28 ) at initial $\mathrm{pH}$ of 6.5 , while those differences were not obtained with low concentration of $\mathrm{FeSO}_{4} \cdot 7 \mathrm{H}_{2} \mathrm{O}$ among the same initial $\mathrm{pH}$. It was also confirmed that initial $\mathrm{pH}$ affected total ABE significantly more than
ABE-producing Clostridia bacteria, the electron flow is first directed to hydrogen production and the carbon flow to acid biosynthesis (acetic and butyric acids). The breakdown of glucose to acetyl coenzyme A provides the cell with reducing equivalents. To recycle $\mathrm{NAD}^{+}, \mathrm{NADH}$ is oxidized by NADH ferredoxin reductase, while hydrogenase oxidizes reduced ferredoxins to produce molecular hydrogen (Adams et al. 1980). On the other hand, the solventogenic phase is initiated with accumulation of the fatty acids; both electron and carbon flows are directed to $\mathrm{ABE}$ production via ferredoxins $\mathrm{NAD}(\mathrm{P})^{+}$reductase also 
Table 2 Results of statistical analysis using ANOVA Two-Factor without replication for the effect of $\mathrm{FeSO}_{4} \cdot 7 \mathrm{H}_{2} \mathrm{O}$ concentrations and initial $\mathrm{pH}$ on ABE fermentation by $C$. saccharoperbutylacetonicum N1-4 (ATCC 13564) using glucose as the substrate in defined TYA media

\begin{tabular}{|c|c|c|c|}
\hline Source of Variation & $\mathrm{F}$ & P-value & F-critical \\
\hline $\mathrm{FeSO}_{4} \cdot 7 \mathrm{H}_{2} \mathrm{O}$ concentrations effect on acetone & 1.4 & 0.40 & 9.3 \\
\hline Initial $\mathrm{pH}$ effect on acetone & 7.5 & 0.072 & 10 \\
\hline $\mathrm{FeSO}_{4} \cdot 7 \mathrm{H}_{2} \mathrm{O}$ concentrations effect on butanol & 5.9 & 0.090 & 9.3 \\
\hline Initial $\mathrm{pH}$ effect on butanol & 2.1 & 0.24 & 10 \\
\hline $\mathrm{FeSO}_{4} \cdot 7 \mathrm{H}_{2} \mathrm{O}$ concentrations effect on ethanol & 6.2 & 0.084 & 9.3 \\
\hline Initial $\mathrm{pH}$ effect on ethanol & 4.4 & 0.13 & 10 \\
\hline $\mathrm{FeSO}_{4} \cdot 7 \mathrm{H}_{2} \mathrm{O}$ concentrations effect on $\mathrm{ABE}$ & 8.4 & 0.057 & 9.3 \\
\hline Initial $\mathrm{pH}$ effect on $\mathrm{ABE}$ & 78 & 0.003 & 10 \\
\hline
\end{tabular}

aldehyde and alcohol dehydrogenases. ABEproducing Clostridia bacteria were known to posses the metalloenzymes, hydrogenase and NADH-ferredoxin reductase, which mediate hydrogen formation containing iron clusters and a unique type of Fe-S centre termed the $\mathrm{H}_{2}$ cluster (Adams 1990; Santangelo et al. 1995). The iron clusters serve to transfer electrons between the hydrogen cluster and the external electron carrier (Adams 1990). Hence, it was expected that iron supplementation would facilitate hydrogenase biosynthesis and hydrogen evolution, whereas iron limitation could severely affect the enzyme's biosynthesis and function which would then shift the metabolic pathway to $\mathrm{ABE}$ production (Bahl et al. 1986; Ferchichi et al. 2005; Peguin and Soucaille 1995).

Our results demonstrated that under $\mathrm{FeSO}_{4} \cdot 7 \mathrm{H}_{2} \mathrm{O}-$ limited conditions, strain N1-4 could produce higher $\mathrm{ABE}$ concentrations than under positive control conditions which were usually applied in our ABE group using high iron concentration. These were in agreement with previous studies employing $C$. acetobutylicum (Bahl et al. 1986; Junelles at al. 1988). The data obtained by Junelles et al. (1988) clearly showed that $\mathrm{FeSO}_{4} \cdot 7 \mathrm{H}_{2} \mathrm{O}$ limitation causes a decrease of hydrogenase specific activity and under $\mathrm{FeSO}_{4} \cdot 7 \mathrm{H}_{2} \mathrm{O}$ limitation, acid production is limited but butanol production specifically enhanced by alteration of the carbon and electron pathways present in $C$. acetobutylicum. Their results were in agreement with those of Kim et al. (1984), Meyer et al. (1986), Dabrock et al. (1992), and of Datta and Zeikus (1985), who used carbon monoxide to inhibit hydrogenase either in C. acetobutylicum or C. pasteurianum.

A previous study by Bahl et al. (1986) also revealed that under $\mathrm{FeSO}_{4} \cdot 7 \mathrm{H}_{2} \mathrm{O}$ limitation, lactate instead of butyrate and acetate became the predominant product at $\mathrm{pH}>5$, whereas at lower $\mathrm{pH}$ the lactic acid was replaced by butanol production; the highest butanol production was found at $\mathrm{pH} 4.4$. Our results similarly display the higher lactate production under $\mathrm{FeSO}_{4} \cdot 7 \mathrm{H}_{2} \mathrm{O}$-limited TYA medium with initial $\mathrm{pH} 6.5$ than that with initial $\mathrm{pH} 4.4$ (data not shown). On the other hand, under $\mathrm{FeSO}_{4} \cdot 7 \mathrm{H}_{2} \mathrm{O}$-limited TYA medium with initial $\mathrm{pH} 4.4$ there was a higher butanol production than that with initial $\mathrm{pH}$ 6.5. This could be suggested to be caused by a partial inactivation of the hydrogenase enzyme at low $\mathrm{pH}$ as found by Andersch et al. (1983); inhibition of hydrogenase enzyme resulted in an increase in the butanol production.

In addition, ABE-producing Clostridia bacteria need iron ions for the growth and $\mathrm{ABE}$ production (Gottschalk 1986), therefore $\mathrm{Fe}^{2+}$ is supplemented in the medium at $10^{-5}-10^{-4} \mathrm{M}$. It was found in a study by Ogata et al. (1986) also employing strain N1-4, that $\mathrm{Fe}^{2+}$ was accumulated from the medium by the cells in proportion to their growth, and more of it was selectively accumulated into the cell walls than any of the other metal ions. They also found that the Fe ions were removed from the medium throughout the log phase and the removal rate was very high at the middle to late log phase (6-12 h). It was then confirmed that there is a close relationship between $\mathrm{Fe}^{2+}$ uptake and cell growth with butanol production. Nevertheless, it was not clear that $\mathrm{Fe}^{2+}$ had a high affinity with the peptidoglycan moiety of cell wall by in vivo and in vitro 
accumulation tests; the protoplasmic membrane also contained $\mathrm{Fe}$ at a high level. The selective assimilation of Fe in cell wall peptidoglycan was thought to be the first step in its transport into the protoplasmic membrane and protoplasm. There, many ferredoxins and other Fe-containing compounds must act in cell growth and butanol production. Interestingly, the data of our study show that strain N1-4 could still grow and produce ABE yields, although in lower states than the other treatments, in the negative control treatments with no addition of $\mathrm{FeSO}_{4} \cdot 7 \mathrm{H}_{2} \mathrm{O}$ into the TYA media at both initial $\mathrm{pH}$ values ( $\mathrm{pH} 4.4$ or $\mathrm{pH} 6.5$ ). Therefore, it could be suggested that the $\mathrm{FeSO}_{4} \cdot 7 \mathrm{H}_{2} \mathrm{O}$ is not the limiting factor for the growth and $\mathrm{ABE}$ production of strain N1-4 using glucose as the substrate in the chemically defined TYA medium.

Our statistical analysis resulted that the initial $\mathrm{pH}$ had a significant effect on the ABE production by strain $\mathrm{N} 1-4$, and that the effect of initial $\mathrm{pH}$ was much greater than the effect of $\mathrm{FeSO}_{4} \cdot 7 \mathrm{H}_{2} \mathrm{O}$ concentrations on $\mathrm{ABE}$ production in the TYA media using glucose as the substrate. These were in accordance with previous studies employing a number of $C$. acetobutylicum DSM strains, which reported the $\mathrm{ABE}$ production only below about pH 5.0 using such strains (Andersch et al. 1983; Bahl et al. 1984; Nishio et al. 1983). Additionally, it was known than at pH 6.0 only $6 \%$ of the total amount of butyrate is in the undissociated form, whereas at $\mathrm{pH}$ $4.5,66 \%$ occurs in the undissociated form (Jones and Woods 1986); therefore it could be the reason of higher ABE production with initial $\mathrm{pH} 4.4$ than with initial $\mathrm{pH}$ 6.5 as obtained in our experiment. To the best of our knowledge, our study can be considered as a novel study about the effect of nutrients and initial $\mathrm{pH}$ on the ABE fermentation by strain N1-4 in the defined TYA media.

\section{REFERENCES}

Adams MW. 1990. The structure and mechanism of ironhydrogenases. Biochim Biophys Acta. 1020(2):115145. doi:10.1016/0005-2728(90)90044-5.

Adams MW, Mortenson LE, Chen JS. 1980. Hydrogenase. Biochim Biophys Acta. 594(2-3):105-176.

Amador-Noguez D, Feng XJ, Fan J, Roquet N, Rabitz H, Rabinowitz JD. 2010. Systems-level metabolic flux profiling elucidates a complete bifurcated tricarboxylic acid cycle in Clostridium acetobutylicum. J Bacteriol. 192(17): 4452-4461. doi: 10.1128/JB.00490-10.

Andersch W, Bahl H, Gottschalk G. 1983. Level of enzymes involved in acetate, butyrate, acetone, and butanol formation by Clostridium acetobutylicum. Eur J Appl Microbiol
Biotechnol. 18(6):327-332. doi:10.1007/BF00504740.

Awang GM, Ingledew WM, Jones GA. 1992. The effect of fermentable carbohydrate on sporulation and butanol production by Clostridium acetobutylicum P262. Appl Microbiol Biotechnol. 38(1): 12-16.doi:10.1007/BF001 69411.

Bahl H, Andersch W, Braun K, Gottschalk G. 1982. Effect of $\mathrm{pH}$ and butyrate concentration on the production of acetone and butanol by Clostridium acetobutylicum grown in continuous culture. Eur J Appl Microbiol Biotechnol. 14(1):17-20. doi:10.1007/BF00507998.

Bahl H, Gottschalk G. 1984. Parameters affecting solvent production by Clostridium acetobutylicum in continuous culture. Biotechnol Bioeng Symp. $14(1): 215-223$.

Bahl H, Gottwald M, Kuhn A, Rale V, Andersch W, Gottschalk G. 1986. Nutritional factors affecting the ratio of solvents produced by Clostridium acetobutylicum. Appl Environ Microbiol. 52(1):169172.

Dabrock B, Bahl H, Gottschalk G. 1992. Parameters affecting solvent production by Clostridium pasteurianum. Appl Environ Microbiol. 58(4):12331239.

Datta R, Zeikus JG. 1985. Modulation of acetone-butanolethanol fermentation by carbon monoxide and organic acids. Appl Environ Microbiol. 49(3):522-529.

Devore J, Peck R. 1993. Statistics: The exploration and analysis of data. $2^{\text {nd }}$ Ed. Belmont, California 94002: Wadsworth Publishing Co.

Dubois M, Gilles KA, Hamilton JK, Rebers PA, Smith F. 1956. Colorimetric method for determination of sugars and related substances. Anal Chem. 28(3): 350-356. doi:10.1021/ac60111a017.

Ferchichi M, Crabbe E, Hintz W, Gil G-H, Almadidy A. 2005. Influence of culture parameters on biological hydrogen production by Clostridium saccharoperbutylacetonicum ATCC 27021. World J Microbiol Biotechnol. 21(67):855-862. doi: 10.1007/s11274-004-5972-0.

Formanek J, Mackie R, Blaschek HP. 1997. Enhanced butanol production by Clostridium beijerinckii BA101 grown on semi-defined P2 medium containing 6\% maltodextrin or glucose. Appl Environ Microbiol. 63(6):2306 -2310.

Gottschalk G. 1986. Bacterial metabolism. $2^{\text {nd }}$ Ed. NY, Tokyo: Springer-Verlag.

Heluane H, Evans MR, Dagher SF, Bruno-Barcena JM. 2011. Meta-analysis and functional validation of nutritional requirements of solventogenic Clostridia growing under butanol stress conditions and coutilization of D-glucose and D-xylose. Appl Env Microbiol. 77(13): 4473-4485. doi: 10.1128/AEM.00116-11.

Hipolito CN, Crabbe E, Badillo CM, Zarrabal OC, Mora MAM, Flores GP, Cortazar MAH, Ishizaki A. 2008. Bioconversion of industrial wastewater from palm oil processing to butanol by Clostridium saccharoperbutylacetonicum N1-4 (ATCC 13564). J Clean Prod. 16(5):632 -638. doi: 10.1016/j.jclepro.2007.02.005. 
Jesse TW, Ezeji TC, Qureshi N, Blaschek HP. 2002. Production of butanol from starch-based waste packing peanuts and agricultural waste. J Ind Microbiol Biotechnol.29(3):117-123. doi: 10.1038/sj.jim.7000285.

Jones DT, Woods DR, 1986. Acetone-butanol fermentation revisited. Microbiol Rev. 50(4): 484-524.

Junelles AM, Janati-Idrissi R, Petitdemange H, Gay R. 1988. Iron effect on acetone-butanol fermentation. Curr Microbiol.17(5):299-303. doi: 10.1007/BF01571332.

Kim BH, Bellows P, Datta R, Zeikus JG, 1984. Control of carbon and electron flow in Clostridium acetobutylicum fermentations: utilization of carbon monoxide to inhibit hydrogen production and to enhance butanol yields. Appl Environ Microbiol. 48(4): 764-770.

Meyer CL, Roos JW, Papoutsakis ET. 1986. Carbon monoxide gasing leads to alcohol production and butyrate uptake without acetone formation in continuous culture of Clostridium acetobutylicum. Appl Microbiol Biotechnol. 24(2):159-167. doi: 10.1007/BF01982561.

Monot F, Engasser JM, Petitdemange H, 1984. Influence of $\mathrm{pH}$ and undissociated butyric acid on the production of acetone and butanol in batch cultures of Clostridium acetobutylicum. Appl Microbiol Biotechnol. 19(6):422426. doi: 10.1007/BF00454381.

Monot F, Martin JR, Petitdemange H, Gay R. 1982. Acetone and butanol production by Clostridium acetobutylicum in a synthetic medium. Appl Environ Microbiol. 44(6):1318-1324.

Nishio N, Biebl H, Meiners M. 1983. Effect of $\mathrm{pH}$ on the production of acetone and butanol by $C$. acetobutylicum in a minimum medium. J Ferment Technol. 61(1):101104.

Ogata S, Fujino K, Yoshino S, Hayashida S, Yuita K. 1986. Selective accumulation of iron ion into the cell wall of
Clostridium saccaharoperbutylacetonicum ATCC 13564. J Gen Appl Microbiol. 32(2): 101-109.

Peguin S, Soucaille P. 1995. Modulation of carbon and electron flow in Clostridium acetobutylicum by iron limitation and methyl viologen addition. Appl Environ Microbiol. 61(1): 403-405.

Qureshi N, Blaschek HP. 2001.ABE production from corn: A recent economic evaluation. J Ind Microbiol Biotechnol. 27(5):292-297. doi: 10.1038/sj.jim.7000123.

Qureshi N, Li XL, Hughes S, Saha BC, Cotta MA. 2006. Butanol production from corn fiber xylan using Clostridium acetobutylicum. Biotechnol Prog. 22: 673680. doi: 10.1021/bp050360w.

Santangelo JD, Durre P, Woods DR. 1995. Characterization and expression of the hydrogenase-encoding gene from Clostridium acetobutylicum P262. Microbiology. 141(1): 171-180. doi: 10.1099/00221287-141-1-171.

Tashiro Y, Sonomoto K. 2010. Advances in butanol production by clostridia. In: Mendez-Vilas, A. (Ed.), Current Research, Technology and Education Topics in Applied Microbiology and Microbial Biotechnology (Microbiology Book Series, number \#2). FORMATEX, Spain:1383-1394.

Tashiro Y, Shinto H, Hayashi M, Baba S, Kobayashi G, Sonomoto K. 2007. Novel high-efficient butanol production from butyrate by non-growing Clostridium saccharoperbutylacetonicum N1-4 (ATCC 13564) with methyl viologen. J Biosc Bioeng. 104(3): 238-240. doi: 10.1263/jbb.104.238.

Tashiro Y, Takeda K, Kobayashi G, Sonomoto K, Ishizaki A, Yoshino S, 2004. High butanol production by Clostridium saccharoperbutylacetonicum N1-4 in fed-batch culture with $\mathrm{pH}$-stat continuous butyric acid and glucose feeding method. J Biosci Bioeng. 98(4): 263-268. doi: 10.1263/jbb.98.263. 